\title{
Comparative Book Review
}

Palfrey, ). \& Gasser, U. (2008)

Born digital: Understanding the first generation of digital natives

Tapscott, D. (2009)

Grown up digital: How the Net generation is changing your worla

\section{Janet Martin}

Since Tapscott (1998) first coined the term "Net Generation" and Prensky (2001a) developed a definition and specific characteristics of "Digital Natives" around the turn of the century, debate has raged as to whether this new generation of students requires a complete rethink about the way education should be provided. In his seminal article, Prensky (2001a) claimed "our students have changed radically. Today's students are no longer the people our educational system was designed to teach.... [because of] the arrival and rapid dissemination of digital technology in the last decades of the 20th century." (p. 1)

Ten years on, Palfrey \& Gasser (2008) and Tapscott (2009) contribute to the debate with their much advertised books, Born Digital and Grown up Digital. In both cases these books address issues of change perceived as needed in as wide ranging fields as education, the workforce, consumerism, the family, and society. For this review in a journal on teaching and learning however, concentration will be focused on the debate about the impact of "digital natives" in the development of education into the new millennium. With an increasing amount of empirical research being dedicated to the topic, this debate remains one of the most interesting and relevant of our time. 
Discussions about "digital natives" usually center around an assumption about the existence of a generation of reasonably homogenous young people, born after about 1985, who possess sophisticated knowledge of and skills with information technologies. As Palfrey \& Gasser begin, "All of them are "Digital Natives". They were all born after 1980 .... They all have access to networked digital technologies. And they all have the skills to use those technologies." (p. 1) "They are joined by a set of common practices, including the amount of time they spend using digital technologies, their tendency to multitask, their tendency to express themselves and relate to one another in ways mediated by digital technologies, and their pattern of using the technologies to access and use information and create new knowledge and art forms." (p. 4) After extensive descriptions of characteristics of "digital natives" worldwide however, Palfrey concedes that there is a digital divide - differences in internet access haves and have nots - which make definition of a generation of young people identifiable by their immersion and innate skills with the internet difficult.

While using different terms to describe this younger generation, Tapscott similarly concludes that "the Net Generation is a distinct generation" ( $p$. 11 ), and that "the defining characteristic of an entire generation was that they were the first to be "growing up digital" "(p. 2). They "have a natural affinity for technology that seems uncanny" (p. 9); "they seem to feast on technology and have an aptitude for all things digital that is sometimes mindboggling." (p. 10) Tapscott outlines his belief that "growing up digital has had a profound impact on the way this generation thinks, even changing the way their brains are wired" (p. 10)

Such generalizations do not sit comfortably with many researchers however, who note world- and community-wide variations in connectivity, school and home backgrounds, domestic affluence, and cultural and socia contexts - all factors which undermine the assumption of a comparatively universal and tech-savvy digital generation. (Bennett, Maton, \& Kervin, 2008; Combes, 2009; Hargittai, 2010; Hargittai \& Hinnant, 2008; Jones, Ramanau, Cross, \& Healing, 2010; Kennedy, Judd, Churchward, Gray, \& Krause, 2008; Livingstone \& Bober, 2005; Rowlands, Nicholas, Williams, Huntington, \& Fieldhouse, 2008; Selwyn, 2009) As Kennedy (2008) summarizes, "not only is it assumed that these students will have had broadly universal experiences, but that they will also have a sophisticated knowledge and understanding of information and communication technologies (ICTs). Such generalizations risk overlooking a more complex mix of technology based skills, knowledge and skills among the student population." (p. 109)

With specific reference to education, Palfrey and Tapscott both go on to define new preferred learning styles for "digital natives". General characteristics they accredit to this generation include preferences for multitasking, collaboration, visual learning, and short pieces of information, and the ability of "digital natives" to be critical and questioning, fast and innovative, and tremendously creative. Palfrey asserts that "learning itself has undergone a transformation over the past thirty years. The Internet is changing the way that children - and college students - gather and process information in all aspects of their lives." (p. 239) Tapscott outlines his thoughts about the new generation of learners: "young people seem to lack long attention spans.... Indeed, they show signs of learning differently." (p. 10) He elaborates: "It's not what you know that really counts; it's how you navigate in the digital world, and what you do with the information you discover. This new style of learning, I believe, will suit them. Net Geners, immersed in digital technology, are keen to try new things, often at high speed. They want school to be fun and interesting. So they should enjoy the delight of discovering things for themselves." (p. 134)

Palfrey admits that "there are a lot of excellent questions to be answered about how kids are learning in a digital environment and how that compares to the way they learned in a predominantly analog world." (p. 239) He then continues however, to make claims about how they are learning: "Just because Digital Natives learn differently from the way their parents did when they were growing up doesn't mean that Digital Natives are not learning.... [People] underestimate the depth of knowledge that Digital Natives are obtaining on the Web.... Digital Natives often access much more information about a topic they are interested in than kids of previous generations ever could have." (p. 240) Further, "Digital Natives gather information through a multistep process that involves grazing, a "deep dive", and a feedback loop. They are perfecting the art of grazing through the huge amount of information that comes their way on a daily basis." (p. 241) Palfrey's conclusion therefore, is that educational systems need to adapt to the different learning styles of this new generation: "In order for schools to adapt to the habits of Digital Natives and how they are processing information, educators need to accept that the mode of learning is changing rapidly in a digital age." (p. 239)

To what extent then, do Tapscott and Palfrey's books advocate revolutionizing the education system to suit "digital natives"? Happily, neither appear to advocate the replacement of "outdated language", slow and irrelevant teaching methodologies, and "legacy" content [such as reading, writing and arithmetic] with computer gaming for all students, as recommended by Marc Prensky (2001a, 2001b, 2005, 2008). Both Tapscott and Palfrey however, do use emotive language to describe current educational systems, referring to "industrial age" models of education, which are largely boring, lecture and teacher focused (Tapscott, p. 122), and an "utterly confused", unprogressive educational establishment (Palfrey \& Gasser, p. 239). Both Tapscott and Palfrey recommend a technological make-over of educational systems to enable a transition to education which is relevant to "digital natives", claiming that "students won't be prepared for the world of today unless schools use technology to implement real change to their 
model of education." (Tapscott, p. 144), and that "forward-looking schools know that technology infrastructures are likely to be worthy investments over time. But very few have any idea how to use them.... Very few schools have figured out the connection between how young people are learning in general in a digital age". (Palfrey \& Gasser, p. 239)

Both Tapscott and Palfrey however, temper their recommendations for simple technology solutions with common sense [and already increasingly implemented] recommendations for more student-centered, collaborative and interactive educational environments, facilitated by faculty who have the opportunity for relevant training, and who are incentivized and rewarded for experimentation. As Palfrey concludes, "we don't need to overhaul education to teach kids who are born digital. There is a temptation among those who love technology to promote radical changes in the way we teach our students. It's easy to fetishize technology. That instinct is wrong. Learning will always have certain enduring qualities that have little or nothing to do with technology.... We should figure out, instead, how the use of technologies can support our pedagogical goals." (p. 246)

So, the question must be asked, 'on what basis do Palfrey and Tapscott determine their conclusions?' Both commentators appear to have conducted some empirical work, though apparently more conversational than according to common qualitative or quantitative research practices.

Tapscott starts impressively with the statement that "Grown Up Digital was inspired by a $\$ 4$ million research project, "The Net Generation: A Strategic Investigation", funded by large companies.... Interviewed close to 10,000 people and produced over 40 reports.... " (p. xi) However, as the reports are proprietary to the research sponsors, Tapscott says that he will "share some of the findings and main conclusions throughout this book" (p. 6), confirming that "the opinions expressed in this book are [his]" (p. xi). These opinions are interspersed (often without ability to discern the source) with views and stories from a community on Facebook of over 200 people, a series of online discussions over several months, and the insights and comments of his two children "used throughout the course of the book" (p. 6).

Palfrey states that "our methodology involves a combination of approaches..." (p. 13), including the "research done by others .... a series of focusgroups and interviews of young people" (p.13) (about 100 conversations) as well as "conversations that we held with about 150 additional informants, including other young people, their teachers, librarians, psychologists, and those who study them." (p. 13) While the "goal was not to undertake a comprehensive study", the conclusions reached could have far-reaching implications for the understanding of today's students, as well as for review of our current educational systems, if taken seriously.

Certainly the publications of such commentators have received wide publicity and excellent sales, with Tapscott himself documenting that his first book Growing Up Digital (1998) "was, for a while, the bestselling nonfiction book on Amazon.com and won the first ever Amazon.com bestseller award in the nonfiction category." (p. 2) As Combes (2009) points out, "these publications use the Internet and the World Wide Web (WWW) as a global advertising forum and as a consequence have been picked up by the popular press, to such an extent that these labels and attributes said to characterize the members of Gen Y now appear to have become accepted as a universal social phenomenon. The nature of the Internet not only ensures the global acceptance of an intuitive user, but also allows it to be maintained and constantly recycled." (p. 1)

There are several possible reasons for the popularity and support for such viewpoints "repeatedly ... reproduced as if they were supported by empirical evidence" (Bennett et al., 2008, p. 782), aside from the marketing success of the Internet and the media in reproducing anecdotes and appeals to common-sense beliefs.

For the general public, especially for older citizens, the Internet and the effect of the Net on young people is often a topic of fear and the unknown. "News coverage is saturated with frightening stories of cyberbullying, online predators, Internet addiction, and online pornography." (Palfrey \& Gasser, p. 8) In response to such news coverage, simple, clear messages of hope are sought and repeated.

On the other hand is what Bennett (2008) refers to as an 'academic moral panic' (p. 782) created by emotive language which labels those who are perceptive and progressive in the inevitable tide of change, and those educational institutions and teachers who dwell in the "Industrial Age model of education" (Tapscott, p. 122). In this debate, Bennett points out that a "divide is then created between those who believe in the digital native phenomenon and those who question it. Teachers who do not change their practices are labeled as 'lazy' and 'ineffective' (Prensky, 2001a). Those who refuse to recognize what is described as an inevitable change are said to be in denial, resistant and out of touch, and are portrayed as being without legitimate concerns (Downes, 2007; Tapscott, 1998)". (pp. 782-783)

Obviously students today who are immersed in an internet world (arguably not a homogenous generation), have different experiences and expectations than their parents or older generations, which are likely to affect their interaction with their educational systems. Educational changes in these circumstances appear inevitable, and would be welcomed by many students and faculty, but should not be made in an atmosphere of haste and threat. While the publications of Tapscott and Palfrey make for entertaining reading, and include many common sense recommendations in places, neither should be considered as an authoritative discourse based on sound research findings. Such research is being undertaken in many countries of the world in recent years, and is developing a global picture that all educators 
should become familiar with, if more complicated than that portrayed in the popular media. This includes research being undertaken in the United Arab Emirates, where cultural considerations only lightly touched on in more general texts form an additional level of understanding for these students of the future, and their important and changing educational needs.

\section{REFERENCES}

Bennett, S., Maton, K., \& Kervin, L. (2008). The 'digital natives' debate: A critical review of the evidence. British Journal of Educational Technology, 39(5), 775-786

Combes, B. (2009). Digital Natives or digital refugees? Why we have failed Gen $Y$ ? Paper presented at the International Association of School Librarianship. Selected Papers from the 2009 Annual Conference, Brantford.

Downes, S. (2007). Places to go: Google's search results for "Net Generation". Innovate, 3(4), 1-4.

Hargittai, E. (2010). Digital Na(t)ives? Variation in Internet skills and uses among members of the "Net Generation". Sociological Inquiry, 80(1), 92113.

Hargittai, E., \& Hinnant, A. (2008). Digital inequality: Differences in young adults' use of the Internet. Communication Research, 35(5), 602-621.

Jones, C., Ramanau, R., Cross, S., \& Healing, G. (2010). Net generation or Digital Natives: Is there a distinct new generation entering university. Computers \& Education, 54, 722-732.

Kennedy, G., Judd, T., Churchward, A., Gray, K., \& Krause, K.-L. (2008). First year students' experiences with technology: Are they really digital natives? Australasian Journal of Educational Technology, 24(1), 108-122.

Livingstone, S., \& Bober, M. (2005). UK children go online: Final report of key project findings. London, UK: UK Children Go Online Project.

Palfrey, J., \& Gasser, U. (2008). Born digital: Understanding the first generation of digital natives. New York: Basic Books.

Prensky, M. (2001a). Digital natives, digital immigrants. On the Horizon, 9(5), $1-6$.

Prensky, M. (2001b). Digital natives, digital immigrants, Part II: Do they really think differently? On the Horizon, 9(6), 1-9.

Prensky, M. (2005). “Engage me or enrage me": What today's learners demand. Retrieved 2 February, 2010, from http://www.marcprensky.com/ writing/Prensky-Engage me_or_Enrage me.pdf
Prensky, M. (2008). Backup education? Too many teachers see education as preparing kids for the past, not the future. Educational Technology, 48(1), $1-3$.

Rowlands, I., Nicholas, D., Williams, P., Huntington, P., \& Fieldhouse, M. (2008). The Google generation: The information behaviour of the researcher of the future. Aslib Proceedings, 60(4), 290-310.

Selwyn, N. (2009). The digital native - myth and reality. Aslib Proceedings, 61(4), 364-379.

Tapscott, D. (1998). Growing up digital: The rise of the Net Generation. New York: McGraw-Hill.

Tapscott, D. (2009). Grown up digital: How the Net generation is changing your world. New York: McGraw Hill. 